\title{
IMPACTS OF HORIZONTAL INTEGRATION ON CZECH RETAIL STORES WITH FAST-MOVING GOODS
}

\author{
[Dopady horizontální integrace na české maloobchodní prodejny \\ s rychloobrátkovým zbožím] \\ Michal Paták ${ }^{1}$, Lenka Branská ${ }^{2}, Z_{\text {Zuzana Pecinová }}^{3}$ \\ ${ }^{1}$ University of Pardubice, Faculty of Chemical Technology, Studentská 95,532 10 Pardubice \\ Email: michal.patak@upce.cz \\ ${ }^{2}$ University of Pardubice, Faculty of Chemical Technology, Studentská 95,532 10 Pardubice \\ Email: lenka.branska@upce.cz. \\ ${ }^{3}$ University of Pardubice, Faculty of Chemical Technology, Studentská 95,532 10 Pardubice \\ Email: zuzana.pecinova@upce.cz
}

\begin{abstract}
Horizontal integration is currently an opportunity to increase the performance of organizations. While being possible with various entities, it is typical for retail stores and companies that provide paid logistics services. The literature deals with the benefits of horizontal integration and barriers to implementation. So far, however, it has not addressed the results of horizontal integration, i.e. perception of their advantages and disadvantages after the integration process. The paper expands the theoretical knowledge in the field of disadvantages of implemented horizontal integration. It presents the results of primary quantitative research carried out in 142 retail stores. Managers of integrated stores consider the limited influence on the type and breadth of the assortment sold as well as on the setting of prices, margins, and the need to adhere to a uniform visual style of the store to be the biggest disadvantage. Managers of independent stores do not perceive the problem of limiting the influence on the type and breadth of the assortment sold so significantly, but much more significantly than managers of integrated stores, they see the disadvantage in the lower quality of delivered goods, limited influence on the distribution of created financial resources and distortion of market information.
\end{abstract}

Keywords: fast-moving consumer goods, horizontal integration, retail, supply chain management.

JEL classification: L81, L22, N31

Received: 23.7.2020; Reviewed: 27.7.2020; 20.8.2020; Accepted: 9.9.2020

\section{Introduction}

At present, it is already a generally accepted fact that a significant shift in the company's performance can be achieved through integration activities. Taking various forms, they are common in the field of supply chain management. Their goal is to increase the performance of links involved in integrations.

While the reasons, expected benefits, and barriers to integration are addressed relatively extensively in the literature, the issue of the result, especially horizontal integration (i.e. its functionality and the actual advantages and disadvantages) is addressed insufficiently. So far, it is not at all clear what advantages and disadvantages occur after the completion of the integration process. Nevertheless, identifying advantages, and especially disadvantages, is important for more successful integration activities in the future. It is because it is easier, for the time being, to solve horizontal integration in theory than in practice (Yuen et al. 2019). 
The paper aims to define the disadvantages of horizontal integration from the point of view of retail store managers. To meet the goal thus defined, primary quantitative research was carried out in retail stores selling fast-moving goods in the Czech Republic.

The paper first defines the theoretical basis as the starting point of primary quantitative research, followed by the research methodology and its results. Based on the analysis of research results, the disadvantages of horizontal integration are first specified as perceived by the managers of horizontally integrated stores. Subsequently, a comparison is made with the attitudes of managers of independent retail stores. The aim of the final stage of evaluating the results of primary quantitative research is to determine the degree of consistency in the perception of the expected and actual disadvantages of horizontal integration.

\section{Theoretical basis - horizontal integration, its benefits and barriers to implementation}

The basic integration activities in the field of supply chain management include vertical and horizontal integration (Barratt 2004). Vertical integration involves suppliers and customers within a single supply chain, often from the input of primary raw materials to the production and sale of end-use products (Blaháček et al. 2017). Vertical integration is about developing cooperation between suppliers, manufacturers, and business intermediaries (including retailers).

Unlike vertical integration, horizontal integration connects the links of different supply chains (Basso et al. 2019). According to the European Union (European Union: Guidelines on the applicability of article 81 of the EC treaty to horizontal cooperation agreements), horizontal cooperation is defined as the joint effort of companies operating at the same level of the supply and demand system. These companies can be supply chain participants operating at different levels, i.e. manufacturers, their suppliers, or retailers (Cruijssen 2006). It is typical for retail stores and, in the case of logistics service providers (such as transport or warehousing), to be paid.

Horizontal integration is usually carried out by competing businesses (Basso et al. 2019; Cruijssen et al. 2007b) or independent businesses (Cruijssen et al. 2007b) for mutual benefit. Its wider application also supports standardization, especially in the provision of products and services (Butler 1997).

Horizontal cooperation is an innovative solution that will effectively address the growing logistical challenges from both an environmental and an economic point of view (Pomponi et al. 2013). It provides an opportunity for future improvement of the performance of companies involved in a horizontal grouping (Rodriguez et al. 2015).

However, the degree of performance improvement depends on the functioning of the horizontal grouping itself. This primarily determines the degree of horizontal integration. Cruijssen et al. (2007b) state that the breakdown according to Lambert et al. (1999) can be used to define the degree of horizontal integration:

1. Type I - cooperation takes place between mutually respecting partners. To a limited extent, they coordinate the planning and performance of their activities. Cooperation takes place at the operational or tactical level and concerns selected areas of activities or divisions.

2. Type II - partners not only coordinate but also integrate part of their business planning. The time horizon has a strategic dimension, but the duration of cooperation is not unlimited. However, it covers more areas of activities or divisions. 
3. Type III - partners significantly integrate their activities and each considers their partner to be an extension of their own entity. Cooperation has a strategic dimension; it is not expected to end. According to Cruijssen et al. (2007b), this integration link is called a strategic alliance, and the cooperation is based on a contractual agreement.

The literature deals with the advantages of horizontal integration and the problems associated with its implementation. Attention is focused mainly on the horizontal integration of companies providing logistics services (e.g. Cruijssen et al. 2007b; Krajewska et al. 2008), and, according to Naesensen et al. (2007), less attention is paid to the integration activities of retail stores.

The benefits of horizontal integration are described exhaustively by academics. In the area of preparation of business activities of the horizontal grouping, it is mainly about better access to market information (Pawlewicz 2014) and sharing thereof (Cruijssen et al. 2007b). In the field of implementation of these activities, the literature mentions, in particular, the possibility of overcoming financial (Hingley et al. 2011) and legislative barriers to trade (Cruijssen et al. 2007b), easier access to loans (Pawlewicz 2014), risk-sharing (Amer, Eltawil 2015), knowhow sharing (Amer, Eltawil 2015; Cruijssen et al. 2007a), resource sharing (Cruijssen et al. 2007b; Prakash, Deshmukh 2010; Hingley et al. 2015) and increasing bargaining power over suppliers (Rodriguez et al. 2015). Finally, several advantages can also be found in the evaluation of the resulting success of groups and companies. These include increasing the level of services provided (Cruijssen et al. 2007a,b; Rodriguez et al. 2015; Pawlewicz 2014; Fernie et al. 2000; Vanovermeire et al. 2014), increasing employee skills (Cruijssen et al. 2007b), inventory reduction (Fernie et al. 2000), image growth (Cruijssen et al. 2007b), improving market position (Cruijssen et al. (2007a), increasing revenues (Butler 1997) and profit (Hill, Jones 2009), higher sales guarantee (Pawlewicz 2014) and other environmental and social benefits (Amer, Eltawil 2015).

By contrast, the area of barriers to horizontal integration is less explored. Insufficiently described are not only the problems associated with it (Naesens et al. 2007) but also the reasons for the failure of the integration process (Yuen et al. 2019).

In the area of preparation for integration, the main barriers to horizontal integration are considered to be the need to optimize the number of participants in a horizontal grouping (Basso et al. 2019), the need to harmonize or share interests (Cruijssen et al. 2007b) and business principles (Basso et al. 2019), the need to establish the management of the whole group (Cruijssen et al. 2007b; Chen, Tan 2018), the need to implement information and communication technologies (Rodriguez et al. 2015) and set up the right information flow (Basso et al. 2019), and the need to re-engineer processes (Smith, Sparks 2004); Fernie et al. 2010). The main barriers associated with the implementation of horizontal integration are higher costs (Cruijssen et al. 2007b), the elimination of conflicts and opportunism (Wallenburg, Raue 2011), the loss of identity (Cruijssen et al. 2007b) and competitive advantages (Stephens, Wright 2002; Hingley et al. 2011), but also the loss of profitability, for example in connection with changes in the payment of taxes (Pawlewicz 2014).

However, if the emerging barriers are successfully removed during the implementation process, a horizontal grouping should be created that provides the expected benefits and advantages. Still, the truth is that horizontal integration can also have many disadvantages. However, the literature does not mention them yet. Therefore, to fill this gap in theoretical knowledge, primary quantitative research was carried out. 


\section{Research methodology}

The primary quantitative research aimed to identify the main disadvantages of horizontal integration of retail stores from the perspective of managers of integrated stores and to compare managers' attitudes to these disadvantages depending on whether they manage a store that is integrated into the retail chain or not.

Data were collected by the method of interviewing store managers using a structured questionnaire. Since there is no suitable selection support for research in stores with fastmoving consumer goods, deliberate selection techniques were used in the data collection. The selection criterion was mainly the size of the sales area, which reflected trends in the development of the structure of stores in the Czech Republic (Nielsen 2016; SOCR ČR and Nielsen 2019). To ensure sufficient variability of stores in the research sample (and thus increase its representativeness), 142 stores from various regions of the Czech Republic, from different-sized municipalities, with various types of fast-moving goods in the sales range and belonging to various retail chains, were included in the research. However, the research sample can only be considered representative with regard to the size of the sales area. The structure of the research sample of retail stores is shown in Table 1.

Table 1: The structure of the research sample of retail stores

\begin{tabular}{|l|l|c|}
\hline Sorting attribute & Store type & Percentage (\%) \\
\hline \multirow{3}{*}{ Integration into the retail chain } & Independent store & 44 \\
\cline { 2 - 3 } & Chain store & 56 \\
\hline \multirow{3}{*}{ Size of the sales area } & Up to $50 \mathrm{~m}^{2}$ & 37 \\
\cline { 2 - 3 } & $51-400 \mathrm{~m}^{2}$ & 50 \\
\cline { 2 - 3 } & Over $400 \mathrm{~m}^{2}$ & 13 \\
\hline
\end{tabular}

Source: own

As part of the survey, respondents' attitudes to the disadvantages of horizontal integration of stores into retail chains were measured. The respondents were asked to select a maximum of three main disadvantages of horizontal integration from a list of twelve pre-specified disadvantages. The specified disadvantages were based on the expert judgment and experience of the authors from previous research in retail stores. For this reason, respondents could specify another significant disadvantage if it was not included in the list. This option was used by 8 (6 percent) respondents, but in all cases, it was a more detailed specification of a disadvantage that was already generally part of the list of examined disadvantages. For this reason, the list of disadvantages that have been included in the research can be considered exhaustive.

The data obtained were analysed by selected methods of exploratory and inferential statistics using statistical software IBM SPSS Statistics. The data analysis took into account whether the store currently belongs to a retail chain or is an independent store. The statistical significance of differences in respondents' attitudes (or the perceived importance of the disadvantages of horizontal integration) was verified by Pearson's chi-square test at a significance level of 5 percent.

\section{Research results}

Through the implemented quantitative research, a number of disadvantages of horizontal integration were revealed, but some of them are considered by retail store managers to be more significant (i.e. they were mentioned more often in the research). A comparison of the 
significance of the disadvantages of horizontal integration of retail stores selling fast-moving goods in the Czech Republic is given in Table 2.

It is quite clear that the biggest disadvantage of horizontal integration of retail stores is the restriction of business independence, especially the reduction of the influence over the range of goods (its type and breadth), prices (and thus margins). Significant disadvantages can also be considered to include the loss of one's own identity and the reduction of the influence over the supplier selection.

Concerns about the loss of identity are, according to the literature, one of the cited barriers to horizontal integration (Cruijssen et al. 2007b). The results of the research show that these concerns are justified because, according to the chain store managers, limiting one's own identity is one of the main disadvantages of horizontal integration.

Table 2: Disadvantages of horizontal integration from the point of view of store managers integrated into retail chains

\begin{tabular}{|l|c|c|c|}
\hline \multirow{2}{*}{ Disadvantage of horizontal integration } & \multicolumn{2}{|c|}{$\begin{array}{c}\text { Frequency of } \\
\text { answers }\end{array}$} & $\begin{array}{c}\text { Percentage of } \\
\text { respondents }(\%)\end{array}$ \\
\cline { 2 - 3 } $\begin{array}{l}\text { Limited influence over the type and breadth of the range of goods } \\
\text { sold }\end{array}$ & 32 & 17 & 41 \\
\hline Limited influence over pricing and margins & 32 & 17 & 41 \\
\hline Need to adhere to a uniform visual style of the store & 27 & 15 & 34 \\
\hline Limited influence over supplier selection & 27 & 15 & 34 \\
\hline Higher purchase prices and/or worse payment terms & 14 & 8 & 18 \\
\hline Lower store image & 12 & 6 & 15 \\
\hline Limitation of closer cooperation with suppliers & 9 & 5 & 11 \\
\hline Limited influence over sales promotion & 9 & 5 & \\
\hline Lower quality of supplied goods & 7 & 4 & 11 \\
\hline Lower level of logistics services & 5 & 3 & 9 \\
\hline $\begin{array}{l}\text { Limited influence over the distribution of created financial } \\
\text { resources }\end{array}$ & 5 & 3 & 6 \\
\hline $\begin{array}{l}\text { Distortion of information about customers, competition and market } \\
\text { development }\end{array}$ & 4 & 2 & 6 \\
\hline Total & 183 & 100 & 5 \\
\hline
\end{tabular}

Source: own

The negative perception of the limited influence on the supplier selection is in direct conflict with the theoretically stated advantages (Rodriguez et al. 2015), for which horizontal integration is implemented. If the merger of a larger or large number of retail outlets increases bargaining power vis-à-vis suppliers (Rodriguez et al. 2015) while making it possible to achieve better purchasing conditions (Pawlewicz 2014), this must necessarily mean limiting the influence on supplier selection. Retail stores are likely to find it problematic to lose the opportunity to profit from the mutually beneficial relationships built with suppliers in the past.

In the second part of the statistical analysis of the data, it was examined whether the attitudes of managers to the disadvantages of horizontal integration differ depending on the type of store they manage. The result of this analysis is shown in Table 3. 
It is apparent from Table 3 that attitudes to the disadvantages of horizontal integration are not the same in both groups of respondents. It depends on whether the addressed manager manages a store that is integrated into a retail chain or operates as an independent store. A statistically significant difference $\left(\chi^{2}=8,817 ; P=0,003\right)$ was identified in the attitude to a limited influence over the type and breadth of the range of goods, one of the main disadvantages of horizontal integration. Managers from chain stores reported this disadvantage much more often (41 percent of respondents) than managers from independent stores (17 percent of respondents).

The opposite trend was observed for the attitudes of store managers to less significant disadvantages (lower quality of supplied goods, limited influence over the distribution of created financial resources and distortion of information about customers, competition, and market development). As Table 3 shows, managers reported them much more often from independent retail stores. However, the differences found are not statistically significant due to the low values of the observed frequencies.

Table 3: Comparison of disadvantages of horizontal integration from the point of view of integrated store managers and independent store managers

\begin{tabular}{|l|c|c|c|c|}
\hline \multirow{2}{*}{ Disadvantage of horizontal integration } & $\begin{array}{c}\text { Percentage of respondents } \\
(\%)\end{array}$ & \multicolumn{2}{c|}{ Chi-square test } \\
\cline { 2 - 5 } & $\begin{array}{c}\text { Independent } \\
\text { store }\end{array}$ & Chain store & Chi-square & P \\
\hline $\begin{array}{l}\text { Limited influence over the type and breadth of the range of } \\
\text { goods sold }\end{array}$ & 17 & 41 & 8,817 & 0,003 \\
\hline Limited influence over pricing and margins & 38 & 41 & 0,085 & 0,770 \\
\hline Need to adhere to a uniform visual style of the store & 33 & 34 & 0,011 & 0,916 \\
\hline Limited influence over supplier selection & 35 & 34 & 0,009 & 0,926 \\
\hline Higher purchase prices and/or worse payment terms & 17 & 18 & 0,002 & 0,968 \\
\hline Lower store image & 17 & 15 & 0,133 & 0,715 \\
\hline Limitation of closer cooperation with suppliers & 16 & 11 & 0,607 & 0,436 \\
\hline Limited influence over sales promotion & 10 & 11 & 0,130 & 0,719 \\
\hline Lower quality of supplied goods & 17 & 9 & 2,342 & 0,126 \\
\hline Lower level of logistics services & 8 & 6 & 0,138 & 0,710 \\
\hline $\begin{array}{l}\text { Limited influence over the distribution of created financial } \\
\text { resources }\end{array}$ & 14 & 6 & 2,497 & 0,114 \\
\hline $\begin{array}{l}\text { Distortion of information about customers, competition and } \\
\text { market development }\end{array}$ & 13 & 5 & 2,641 & 0,104 \\
\hline
\end{tabular}

Source: own

Based on the analysis of the research results, it can thus be concluded that horizontal integration does have many perceived disadvantages, but there is no need to be overly worried about lower quality goods, limited influence over the distribution of financial resources generated, and distortion of market information. By contrast, it may come as a surprise to independent retail stores that, once integrated into a retail chain, their influence over the type and breadth of product range sold may be limited.

\section{Conclusion}

The paper elaborates on the issue of the impact of horizontal integration on retail stores. It fills a gap in theoretical knowledge about the disadvantages of horizontal integration. The aim was not only to specify the main disadvantages of horizontal integration of retail stores but 
also to determine whether managers' attitudes to the disadvantages of horizontal integration depend on the type of store they manage. Through the analysis of the results of primary quantitative research in retail stores with fast-moving goods in the Czech Republic, it was found that the biggest disadvantages of horizontal integration are considered by the managers to include the restriction of business independence, especially the reduction of the influence over the range of goods (its type and breadth) and its prices (and thus margins), loss of own identity and limited influence over supplier selection. However, the attitudes of store managers to disadvantages in some cases depend on whether the manager comes from a store that is part of a retail chain or not. The main difference is especially in the perception of the limited influence over the type and breadth of the range of goods sold, which may be surprising after the implementation of horizontal integration, as it is not expected in advance. The expected lower quality of goods, the limited influence over the distribution of created financial resources and the distortion of market information are disadvantages expected rather than real.

Given the method of data collection used, the research results cannot be considered fully generalizable. Nevertheless, they can contribute both to scientific knowledge and to the success of further integrations. We consider it appropriate to continue to verify and deepen them. Further research seems to be appropriate to focus on whether the perception of disadvantages (or advantages) affects the affiliation of the store to a particular retail chain. We assume that the perception of disadvantages (or advantages) can be influenced both by the nationality of the group owner (domestic retail chain versus foreign one) and by the uniqueness of the organization and the style of work of individual retail chains. The results of follow-up research would then make it possible to recommend a suitable way of horizontal integration as well as an optimal organization of activities.

\section{References}

[1] AMER L. E. and A. B. ELTAWIL, 2015. Analysis of quantitative models of horizontal collaboration in supply chain network design towards "green collaborative" strategies. In Proceedings of 2015 International Conference on Industrial Engineering and Operations Management (IEOM.) New York: IEEE, s. 1-10. ISBN 978-1-4799-6065-1.

[2] BARRATT, M., 2004. Understanding the meaning of collaboration in the supply chain. Supply Chain Management, 9(1), 30-42. ISSN 1359-8546.

[3] BASSO, F., S. D'AMOURS, M. RÖNNQVIST and A. WEINTRAUB, 2019. A survey on obstacles and difficulties of practical implementation of horizontal collaboration in logistics. International Transactions in Operational Research, 26(3), 775-793. ISSN 0969-6016.

[4] BLAHÁČEK, D., L. BRANSKÁ, M. PATÁK a Z. PECINOVÁ, 2017. Výhody a nevýhody horizontální integrace maloobchodních prodejen. In: Studentská védecká odborná činnost 2016/2017: sborník př́spěvkỉ. Pardubice: UPA, s. 1-6. ISBN 978-807560-084-4.

[5] BUtler, P., T. W. HAll, A. M. HANNA, L. MENDONCA, B. AUGUSTE, J. MANYIKA and A. SAHAY, 1997. A revolution in interaction. The McKinsey Quarterly (1), 4-23. ISSN 0047-5394.

[6] CRUIJSSEN, F., 2006. Horizontal cooperation in transport and logistics. Phd Thesis. Tilburg: Universiteit van Tilburg. 
[7] CRUIJSSEN, F., M. COOLS and W. DULLAERT, 2007a. Horizontal cooperation in logistics: opportunities and impediments. Transport Research Part E Logistics and Transportation Review, 43(2), 129-142. ISSN 1366-5545.

[8] CRUIJSSEN, F., W. DULLAERT and H. FLEUREN, 2007b. Horizontal cooperation in transport and logistics: A literature review. Transportation Journal, 46(3), 22-39. ISSN 0041-1612.

[9] FERNIE, J., F. PFAB and C. MARCHANT, 2000. Retail grocery logistics in the UK. International Journal of Logistics Management, 11(2), 83-90. ISSN 0957-4093.

[10] FERNIE, J., L. SPARKS and A. MCKINNON, 2010. Retail logistics in the UK: past, present and future. International Journal of Retail and Distribution Management, 38 (11/12), 894-914. ISSN 0959-0552.

[11] Guidelines on the applicability of article 81 of the EC treaty to horizontal cooperation agreements. European Commission Notice 2001/C 3/02, Evropská Unie [online]. [vid. 6. ledna 2020]. Dostupné lex.europa.eu/LexUriServ/LexUriServ.do?uri=CELEX:32001Y0106(01):EN:HTML

[12] HILL, C. W. L. and G. R. JONES, 2009. Essentials of strategic management. 2nd ed. Mason: South-Western. ISBN 13: 978-0-547-19432-5, 10: 0-547-19432-3.

[13] HINGLEY, M., A. LINDGREEN, D. B. GRANT and C. KANE, 2011. Using fourth-party logistics management to improve horizontal collaboration among grocery retailers. Supply Chain Management, 16(5), 316-327. ISSN 1359-8546.

[14] HINGLEY, M., A. LINDGREEN and D. B. GRANT, 2015. Intermediaries in powerladen retail supply chains: An opportunity to improve buyer-supplier relationships and collaboration. Industrial Marketing Management, 50, 78-84. ISSN 0019-8501.

[15] CHEN, Q. and Z. TAN, 2018. Mixed coordination mechanisms for scheduling games on hierarchical machines. International Transactions in Operational Research. [online]. [vid. 6. ledna 2020]. Dostupné z: http://doi.wiley.com/10.1111/itor.12558.

[16] KRAJEWSKA, M. A., H. KOPFER, G. LAPORTE, S. ROPKE and G. ZACCOUR, 2008. Horizontal cooperation among freight carriers: request allocation and profit sharing. Journal of the Operational Research Society, 59(11), 1483-1491. ISSN 01605682 .

[17] LAMBERT, D., M. A. EMMELHAINZ and J. T. GARDNER, 1999. Building successful logistics partnerships. Journal of Business Logistics, 20(1), 165-181. ISSN 0735-3766.

[18] NAESENS, K., L. GELDERS and L. PINTELON, 2007. A swift response tool for measuring the strategic fit for resource pooling: a case study. Management Decision, 45(3), 434-449. ISSN 0025-1747.

[19] NIELSEN, 2016. Trendy v struktuře prodejních kanálů potravin za rok 2016 [on line]. [vid. 30. června 2019]. Dostupné https://www.nielsen.com/cz/cs/insights/article/2016/trends-in-the-structure-of-saleschannels-of-food-for-2016/

[20] PAWLEWICZ, A., 2014. Importance of horizontal integration in organic farming. In G. MASURE, ed. Proceedings of the international scientific conference Economic Science for Rural Development: production and co-operation in agriculture. Jelgava: Latvia University of agriculture, s. 112-120. ISBN 978-9934-8466-1-8. 
[21] POMPONI, F., L. FRATOCCHI, S. R. TAFURI and M. PALUMBO, 2013. Horizontal collaboration in logistics: a comprehensive framework. Research in Logistics \& Production, 3(4), 243-254. ISSN 2083-4942.

[22] PRAKASH, A. and S. G. DESHMUKH, 2010. Horizontal collaboration in flexible supply chains: a simulation study. Journal of Studies on Manufacturing, 1(1), 54-58. ISSN 1737-9393.

[23] RODRIGUEZ, V. S., I. HARRIS and R. MASON, 2015. Horizontal logistics collaboration for enhanced supply chain performance: an international retail perspective. Supply Chain Management, 20(6), 631-647. ISSN 1359-8546.

[24] SMITH, D. and L. SPARKS, 2004. Logistics in Tesco: past, present and future. In: J. FERNIE and L. SPARKS, eds. Logistics and retail management: Insight into current practice and trends from leading experts. London: Kogan Page Limited, s. 101-120. ISBN 0749440910.

[25] SOCR ČR A NIELSEN, 2019. TZ SOCR ČR a Nielsen: Nejmenších prodejen ubývá. Nejvíce se daři diskontům. Češi střídají obchody, ale při výběru nových značek jsou konzervativnější. [on line]. [vid. 30. června 2019]. Dostupné z: http://www.socr.cz/clanek/informace-z-dnesni-spolecne-tiskove-konference-socr-cr-anielsen/

[26] STEPHENS, C. and D. WRIGHT, 2002. The contribution of physical distribution management to the competitive supply chain strategies of major UK food retailers. International Journal of Logistics: Research and Applications, 5(1), 91-108. ISSN 13675567.

[27] VANOVERMEIRE, C., K. SÖRENSEN, A. VAN BREEDAM, B. VANNIEUWENHUYSE and S. VERSTREPEN, 2014. Horizontal logistics collaboration: decreasing costs through flexibility and an adequate cost allocation strategy. International Journal of Logistics: Research and Applications, 17(4), 339-355. ISSN 1367-5567.

[28] WALLENBURG, C. M. and J. S. RAUE, 2011. Conflict and its governance in horizontal cooperations of logistics service providers. International Journal of Physical Distribution and Logistics Management, 41(4), 385-400. ISSN 0960-0035.

[29] YUEN, K. F., X. WANG, F. MA, G. LEE and X. LI, 2019. Critical success factors of supply chain integration in container shipping: an application of resource-based view theory. Maritime Policy \& Management, 46(6), 653-668. ISSN 0308-8839. 